\title{
MUSIUM INTERAKTIF SENI DAN DESAIN
}

\author{
Melanie Regina ${ }^{1)}$, Suwardana Winata ${ }^{2)}$ \\ 1)Program Studi S1 Arsitektur, Fakultas Teknik, Universitas Tarumanagara, melanie.nusacreative@gmail.com \\ 2) Program Studi S1 Arsitektur, Fakultas Teknik, Universitas Tarumanagara, danarsitek@gmail.com
}

\begin{abstract}
Abstrak
Perilaku manusia melihat karya seni bukanlah menjadi hal yang pasif. Perkembangan teknologi mengubah paradigma sebuah objek (karya seni) dalam museum. Kesejamanan tersebut memberikan dampak yang besar di dalam desain perancangan museum. Museum yang kita kenal sebagai bangunan yang penuh dengan nilai historikal dengan nilai edukatif didalamnya menjadi berubah, yang bersifat pasif menjadi aktif, yang tertutup menjadi terbuka. Pola interaksi manusia dan objek melebur satu sama lain ditambah dengan sebuah reformasi alam yang menjadi representasi dari terciptanya sebuah karya seni. Seni bukanlah soal karya yang terlihat, tetapi seni adalah sebuah pandangan yang tercermin antara manusia, obyek dan alam. Museum Interaktif seni dan desain bercerita tentang sebuah makna interaksi, desain ini terletak di konteks perkotaan yang sangat padat. Komunitas yang tercipta karna adanya sebuah kesamaan maupun perbedaan persepsi dengan pengalaman sebuah ruang. Pendekatan akan interaksi tersebut melahirkan sebuah konten yang mengarah kepada kepekaan manusia akan pancaindra. "Lima Pancaindra Manusia" menjadi sebuah alat dari museum interaktif seni dan desain ini. Konten yang akan menggiring pengunjung untuk lebih peka terhadap karya seni yang sangat erat dengan pancaindra. Desain perancangan dilengkapi dengan pengalaman-pengalaman akan representasi alam, menghilangkan sebuah kepenatan dari hiruk pikuk kota dan menjadi tempat untuk manusia berkontemplasi dari kesibukan perkotaan. Desain dilengkapi dengan fungsi yang menunjang produktifitas kota dan menghadirkan lingkungan yang positif untuk menjadikan kota yang hidup selama 24 jam. Museum interaktif seni dan desain hadir untuk lingkungan yang berkelanjutan, mewadahi masyarakatnya untuk semakin peka akan sebuah lingkungan dan menunjang produktifitas yang menjadi sebuah kebutuhan di masa yang akan datang.
\end{abstract}

Kata kunci: aktif; alam; interaksi; museum; pancaindra; perkotaan

\begin{abstract}
Point of view for looking artworks is not passsive anymore. Techonolgy development changed the museum paradigm. Those contemporaneity give huge impact for designing museum. The biggest critic of the museum well known about historical which contain educative value in it, currently that's changing are passive to active, closeness to openess. Pattern of human interaction consubstantiate one each other, that's added with nature reformation which has been invented a artwork. Art is not just about visualization, it is about a point of view which reflects among human, object, and nature. Museum of interactive art and design reveals about a meaning of interaction, this museum is going to locate in urban which have a high density and high urbanization. Community is formed from similarities and differences perception about places. Interaction approach will be able to deliver a content of human perseptiveness. "Five Senses of Human" as tools in this museum. These tools will be lead the visitor to have awareness about artworks (that contain five senses of human". Design equips with a lot of nature experiences, it is will be able to dissociate urban complexity and the design will be able to contemplate citizens from rushed activities. The design contain functions to boost urban productivity and provide positive environment to be 24-hours city. Museum of Interactive art and design presents sustainable environment, to provide the citizens to have awareness about nature and support productivity as a needs in the future.
\end{abstract}

Keywords: active; five senses of human; interaction; museum; nature; urban 


\section{PENDAHULUAN}

Teknologi sudah menjadi bagian dari perilaku kesejamanan millenium. Keterikatan terhadap teknologi merubah setiap perilaku manusia menjadi semakin kaya akan sebuah informasi dan interaksi. NIlai-nilai edukasi dapat diakses dengan mudah oleh adanya teknologi. Begitu pula seni dan desain, pada jaman ini seni dan desain menjadi sebuah gaya hidup baru dan dapat menjadi sebuah kekuatan besar terhadap ekonomi kreatif Indonesia. Berikut adalah grafik dimana pertumbuhan subsektor seni dan desain menjadi hal yang akan berkembang kedepannya.
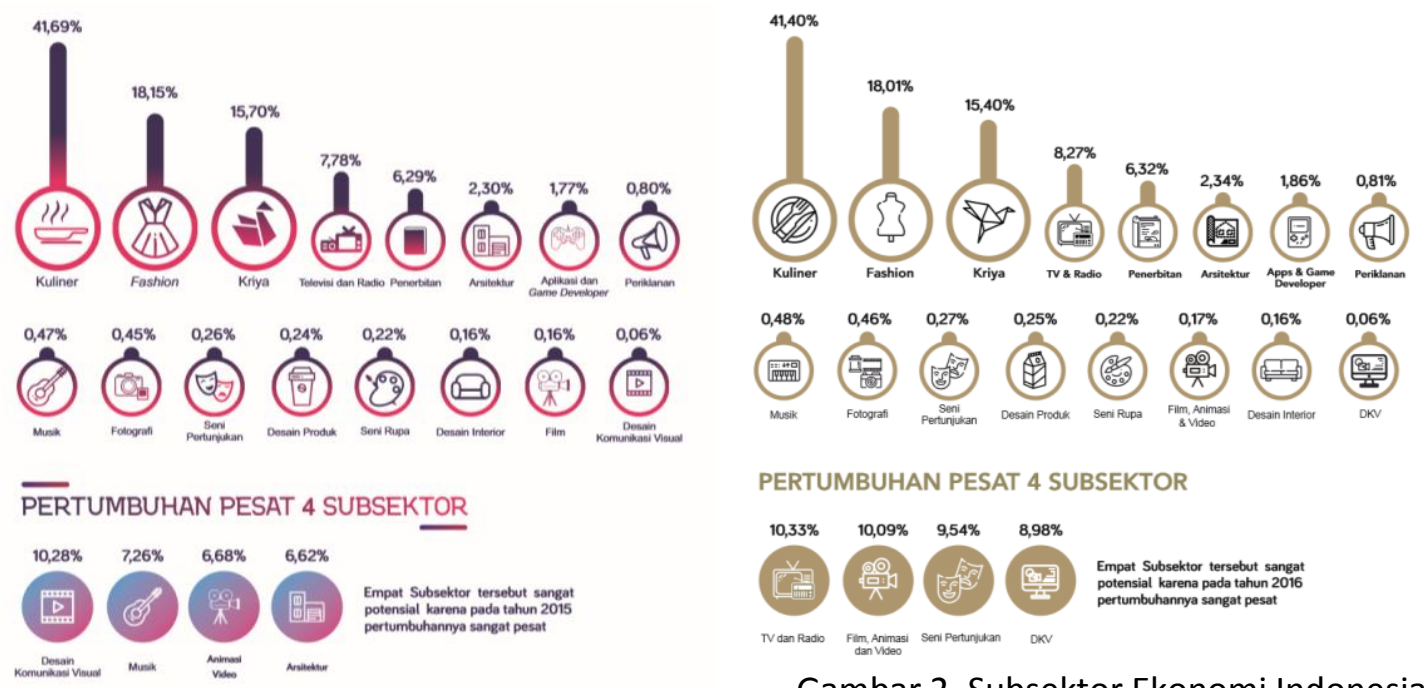

Gambar 1. Subsektor Ekonomi Indonesia Sumber : Bekraf, 2015

PERTUMBUHAN PESAT 4 SUBSEKTOR

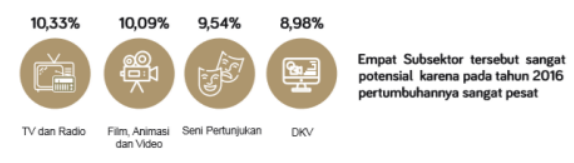

Gambar 2. Subsektor Ekonomi Indonesia Sumber : Bekraf, 2016

Dari gambar 1 dan gambar 2 menunjukkan subsektor ekonomi kreatif didominasi oleh seni dan desain. Pada tahun 2015 pertumbuhan pesat ada pada desain komunikasi visual, musik, animasi video dan arsitektur. Lalu pada tahun 2016 pertumbuhan pesat pada TV dan radio, animasi video, seni pertunjukkan DKV.

Pada hal ini menunjukkan sebuah seni dan desain akan berkembang pesat menjadi sebuah tren pekerja mendatang terutama para millenials. Berikut perkembangan tren tenaga kerja ekonomi kreatif indonesia yang dilakukan oleh Badan Ekonomi Kreatif Indonesia :

\section{TREN TENAGA KERJA EKRAF INDONESIA}

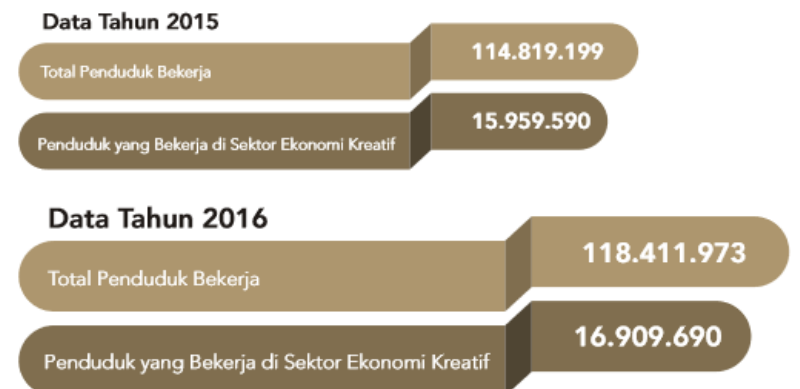

Selama tahun 2015 - 2016, Jumlah Penduduk yang Bekerja di Sektor Ekonomi Kreatif cenderung mengalami peningkatan dari sebesar 15,96 juta orang (13,90\% dari Tenaga Kerja Nasional) pada 2015 menjadi 16,91 juta orang $(14,28 \%$ dari Tenaga Kerja Nasional) pada 2016.

Gambar 3. Tren Tenaga Kerja Ekraf Indonesia Sumber : Bekraf, 2016 
Dengan tren yang ada menjadikan kebutuhan akan sebuah kreativitas dan wadah komunitas semakin bertambah. Dimana pada kesejamanan millenials, seni dan desain merupakan sesuatu hal yang menyatu dengan generasi millenial dan selanjutnya, hal ini menyebabkan adanya sebuah pola perilaku baru mengenai sudut pandang terhadap seni dan desain. Hal ini tidak hanya dapat dirasakan tetapi dapat dilakukan dan menjadi gaya hidup setiap orang.

Begitu pula dengan museum yang kita kenal sebagai sebuah bangunan edukatif yang memiliki nilai historikal yang sangat tinggi tidak sesuai dengan kebutuhan jaman ini. Museum masa kini adalah museum yang memiliki interaksi didalamnya, karena pola kesejamanan millenial menciptakan sebuah pengalaman yang baru terhadap manusianya. Interaksi antar manusia dan objek menjadi hal yang sangat penting dalam sebuah museum. Tetapi kebutuhan millenial tidak sebatas hanya interaksi yang terjadi dengan objek melainkan juga interaksi antar manusianya. Seni dan desain yang sudah menjadi bagian dari generasi milenium menjadi faktor yang akan menambah sebuah komunitas-komunitas itu terjadi. Karakteristik yang mendasar dari sebuah seni dan desain adalah kepekaan antara indera-indera manusia.

Oleh sebab itu museum interaktif seni dan desain ini memberikan sebuah pengalaman baru untuk merangsang kepekaan indera-indera manusia (indra pengecap, penglihatan, penciuman, peraba, pendengar). Alam juga menjadi dasar dari intepretasi seni dan desain, sehingga desain perancangan museum ini menerapkan sebuah ruang yang kaya akan keberadaan alam.

\section{KAJIAN LITERATUR}

\section{Ruang Publik Kota}

Bangunan publik sangat mempengaruhi desain pada perkotaan. Untuk menjadi desain yang berkelanjutan didalamnya harus mencakup beberapa kebutuhan yang sangat erat dengan masyarakat perkotaan yaitu :

Tabel 1. Kebutuhan Manusia-Kriteria dasar untuk bangunan berkelanjutan pada perkotaan

\begin{tabular}{ll}
\hline \multicolumn{1}{c}{ Jenis Kebutuhan } & \multicolumn{1}{c}{ Deskripsi Karakteristik } \\
\hline Menyediakan kebutuhan fisik & $\begin{array}{l}\text { Tempat untuk hidup dan bekerja, penghasilan } \\
\text { yang baik, edukasi dan tempat pelatihan, } \\
\text { mobilitas dan komunikasi, akses pelayanan dan } \\
\text { fasilitas }\end{array}$ \\
\hline Safety, security dan protection & $\begin{array}{l}\text { Secara visual dan secara fungsi mengontrol } \\
\text { sebuah lingkungan, tempat yang bebas polusi dan } \\
\text { kebisingan, tempat yang bebas dari kecelakaan } \\
\text { dan kejahatan }\end{array}$ \\
\hline Lingkungan sosial yang kondusif & $\begin{array}{l}\text { Tempat dimana orang memiliki sumber; rasa } \\
\text { komunitas dan kepemilikan }\end{array}$ \\
\hline Gambaran dan reputasi yang baik & $\begin{array}{l}\text { Sebuah tempat yang memilliki rasa percaya diri } \\
\text { dan kekuatan, tempat dengan sebuah status dan } \\
\text { martabat; kesempatan individual untuk } \\
\text { membentuk ruang personal }\end{array}$ \\
\hline Peluang untuk menjadi kreatif & $\begin{array}{l}\text { Kesempatan komunitas untuk membentuk } \\
\text { lingkungan mereka }\end{array}$ \\
\hline
\end{tabular}

Sebuah tempat yang didesain dengan baik (secara

Secara estetika lingkungan yang menyenangkan estetika); tempat yang secara fisik memiliki sebuah gambaran; kota yang menjadi tempat kebudayaan dan bekerja kesenian

Sumber: http://urbanplanning.uonbi.ac.ke/sites/default/files/cae/artsdesign/urbanplanning/T2-2\%20\%2OURBAN\%20ANALYSIS.pp

Dengan adanya sebuah ruang yang berkontribusi untuk memberikan wadah dan menambah sebuah adanya komunitas baik itu secara visual maupun psikologi, sebuah ruang publik kota akan menjadi berkelanjutan. 


\section{Penghijauan Dalam Bangunan Kota}

Penghijauan bangunan harus memaksimalkan segala aspek dalam sebuah bidang bangunan. Menurut ilmuwan dari Universitas Birmingham dan Lancaster berargumentasi bahwa 'greening up' jalanan dapat mengurangi $30 \%$ reduksi pada polusi udara. Ini berdasarkan riset yang di terbitkan pada jurnal environmental Science and Technology.

Periset menemukan bahwa polusi tidak dapat dengan mudah menghindari "street canyon", 'Green walls' of grass, climbing ivy dan tanaman lainnya memiliki kesempatan yang lebih baik dibanding filtrasi polusi udara daripada mengurangi polusi 1-2\%.

\section{Ruang Pameran Di Dalam Museum}

Untuk para pengunjung, ruang fungsional yang sangat intim dalam arsitektur museum memiliki 3 aspek yaitu Exhibition Space, Traffic Space, dan ruang istirahat (Handerson, 2001).

\section{Exhibition Space}

Objek yang dipilih memiliki keterwakilan dan menjelaskan beberapa aspek ruang arsitektur pameran dalam aspek komposisi ruang dan fungsi organisasi. Berikut ada beberapa tipe museum yaitu : tandem type, radial type dan hall type (Zhang and zhou, 1998). Tandem type bertujuan mengkoneksikan semua ruang pameran; sirkulasi kunjungan yang spesifik dan jelas tapi memiliki kekurangan yaitu kurang fleksibel. Radial type, semua ruang pameran diatur mengelilingi atrium, dimana ini lebih fleksibel dan dapat memilih sebuah ciri khas. Lalu, hall type memusatkan kepada sentralisasi ruang pameran kepada sebuah aula yang komprehensif, dimana tata letak diletakan dengan baik dan fleksibel. Bagaimanapun, ini akan mengakibatkan sebuah rute pengunjung dan gangguan kebisingan menjadi tumpang tindih.

Pada museum memilih sebuah hall type karena selain keterbatasan akan lahan karena memilih konteks bangunan highrise juga memilih tipe tersebut akan kebutuhan dari sebuah ruang yang lebih tertutup. Didalam sebuah studi yang dilakukan oleh Science Direct dalam peneleitian berjudul "A brief analysis of spatial constitution and functional organization of museum architecture: A case study on museums in hafei", menyatakan bahwa sebuah ruang pameran berbentuk kotak sangat relatif tinggi. Tidak ada ruang negatif di dalamnya dan dapat menjadi lebih kondusif untuk perpindahan objek pameran. Pada ruang museum memiliki paling sedikit dua pintu keluar dan pintu masuk di dalam rute pengunjung yang spesifik dan fleksibel.

\section{Traffic Space}

Menurut Yang and Yan (2009), traffic space adalah sebuah penyatu yang menghubungkan banyak ruang, memiliki peran penting di dalam organisasi arus orang dan menuntun para pengunjung. Pada museum interaktif seni dan desain ini memiliki 2 lift kaca dan ramp dimana menjadi benang merah terhadap sebuah desain yang tertutup dan memiliki sebuah pengalaman ruang yang baru yang lebih terbuka. Di dalam museum ini juga terdapat sebuah ruang untuk evakuasi dari 2 sisi yaitu sisi utara dan barat dimana pengunjung terakses dengan mudah dan terlihat oleh pengunjung.

\section{Rest Space}

Menurut sebuah studi oleh Science Direct dalam penelitian yang berjudul "A brief analysis of spatial constitution and functional organization of museum architecture: $A$ case study on museums in hafei" bentuk ruang istirahat di dalam arsitektur museum sangatlah beragam, dimana dapat dibagi menjadi 5 tipe yang mengandung konten di dalamnya :

a. Ruang istirahat spesial.

Posisi dari ruang isitahat ini sangatlah penting. Ruang ini sering dilokasikan di area dimana mengkonsentrasikan aliran pengunjung dan ruang yang tumpang tinding, seperti atrium dan loftly hall. Pada desain museum interaktif seni dan desain ruang istirahat ini terdapat pada lantai 5 dan lantai 5,7M, 14,13. Di dalamnya terdapat beberapa fungsi yaitu reflecting pool, 
ruang semi outdoor, ruang informasi, ruang yang dapat dilakukan untuk acara yang berkaitan dengan konten museum.

b. Ruang isirahat pada lorong.

Pada kasus ini, jenis ruang istirahat ini diatur di sebuah tempat, dimana terjadi persimpangan pada 2 aliran dan percakapan ruang yang terjadi seperti koridor, lorong, tangga, dan ruangan ini biasanya dekat dengan ruang pameran. Di dalamnya terdapat sebuah tempat duduk untuk para pengunjung.

c. Menyiapkan ruang sisa untuk tempat istirahat.

Untuk mendapatkan sensasi terhadap ruang interior yang baik, arsitektur harus memiliki keragaman. Di antara jenis ruang, ada sebuah interlocking space dimana dapat menjadi area untuk istirahat.

d. Ruang istirahat berdekatan dengan fungsi ruang lainnya.

Ruang istirahat berikatan dengan ruang lainnya bertujuan untuk menyediakan pelayanan. Seperti tangga/amphitheater sebagai tempat untuk menyediakan tangga ke fungsi ruang selanjutnya

e. Ruang istirahat yang diletakkan di dalam ruang pameran.

\section{METODE}

Dalam menciptakan sebuah karya arsitektur perlu adanya sebuah tapak yang mendukung sebuah program yang diusulkan. Program yang diusulkan adalah program yang bersifat edukatif, hiburan dan keramahtamahan. Didalamnya terdapat sebuah konteks yang general dan memiliki sebuah target pengunjung yaitu generasi muda yang produktif. Generasi muda akan menjadi sebuah tonggak yang memberikan dampak besar terhadap bangsa. Oleh sebab itu pemilihan lokasi yang tepat adalah di perkotaan padat yang memiliki sebuah kehidupan yang sangat padat dan produktifitas yang sangat tinggi. Selain itu desain sangat dipengaruhi oleh konteks perkotaan dimana kepadatan penduduk menjadikan sebuah bangunan harus beradaptasi dengan lahan yang semakin minim. Oleh sebab itu perancang memberi sebuah ruang yang lebih bebas untuk penghijauan kota dan memilih untuk membangun bangunan highrise untuk terciptanya keharmonisan di dalam perkotaan.

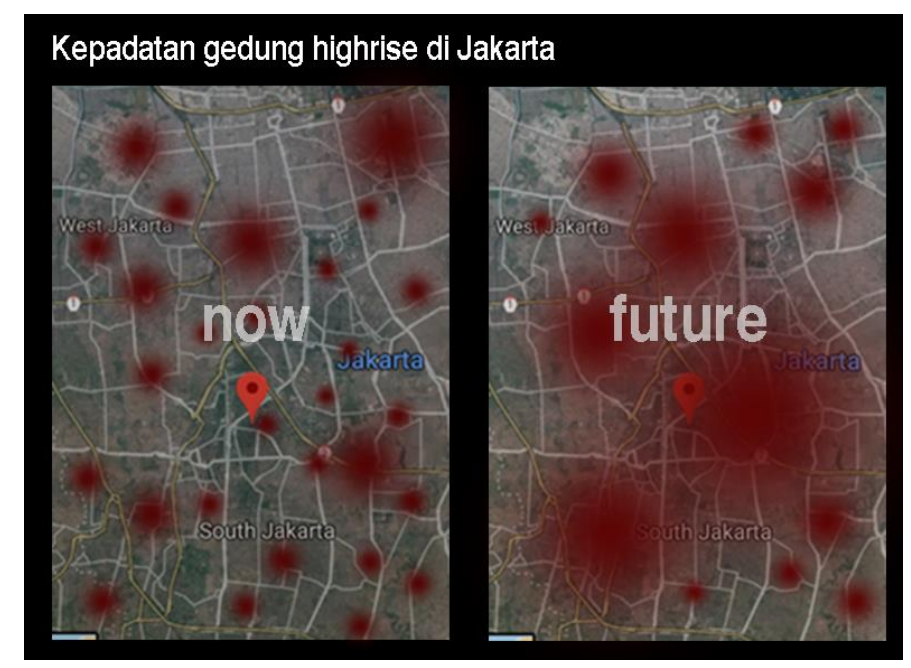

Gambar 4. Kepadatan gedung highrise di Jakarta Sumber: google maps

Kepadatan sebuah perkotaan terutama di Jakarta akan mengakibatkan sebuah perkotaan akan beradaptasi dengan hal tersebut. Pada Gambar 4 menjelaskan bahwa kepadatan bangunan tinggi mendatang di Jakarta akan semakin tinggi (pada gambar bagian kanan). Hal ini akan menyebabkan sebuah permasalahan kota baru yaitu urban canyon (Gambar 5). 

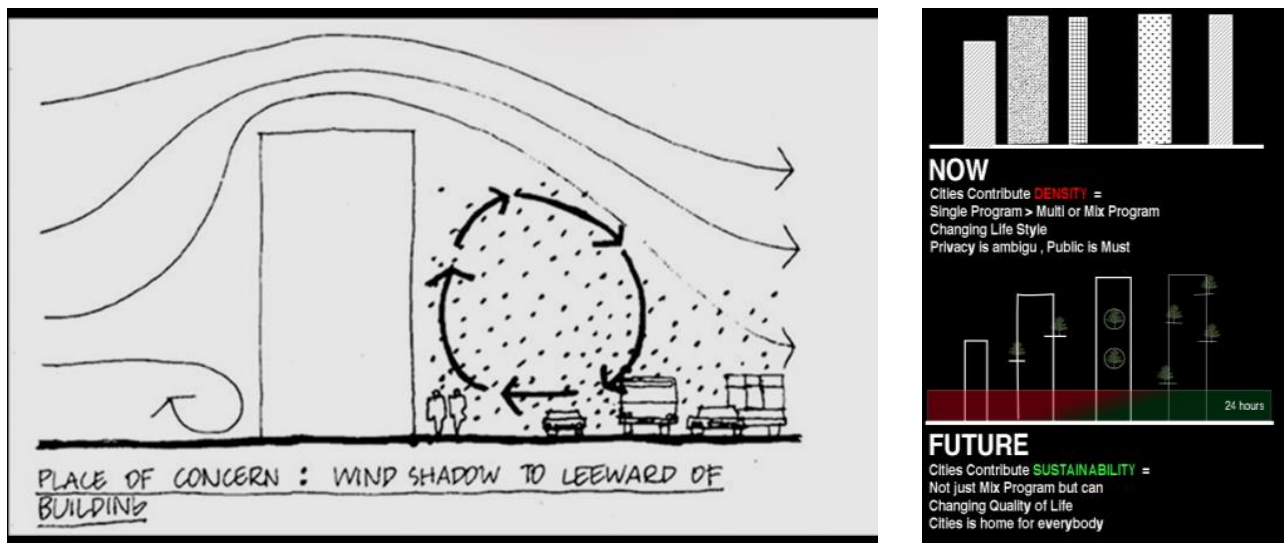

Gambar 5. Urban Canyon

Sumber: Spirn, Anne Whiston "Air quality at the Street Level: Strategies for Urban Design."

Cambridge: Harvard Graduate School of Design, 1986

Bentuk bangunan pada perkotaan akan mempengaruhi panas dan angin. Hal ini akan menghambat dispersi polutan seperti karbonmonoxida, hidrokarbon, dan ozon. Angin yang dihasilkan menjadi tidak sehat akan adanya sebuah reaksi yang terjadi akan hal tersebut.

Bangunan tinggi adalah sebuah adaptasi dari kegiatan yang sangat padat menjadi sebuah kesatuan dalam bangunan. Hal ini menyebabkan kebutuhan akan ruang publik yang semakin banyak dan juga gaya hidup yang berubah, mobilitas menjadi semakin berkonsentrasi kepada pedestrian.

Pada masa yang akan datang dibutuhkan bangunan yang tidak hanya berkontribusi untuk mengatasi kepadatan tetapi juga untuk keberlanjutan sebuah kota. Didalamnya ramah terhadap lingkungan dan dapat memberi kualitas hidup yang baik dari segi lingkungan maupun kegiatannya dan menjadi sebuah ruang publik yang berlangsung selama 24 jam.

Tapak terdapat di Senopati, Jakarta Selatan, dimana luas lahan sebesar 8300m2. Pemilihan tapak berdasarkan kesesuaian akan program ruang yang berdekatan dengan lingkungan yang memiliki produktifitas yang tinggi pada bagian utara tapak, dan lingkungan perumahan serta wadah komunitas untuk generasi yang sedang menginjak usia produktif.

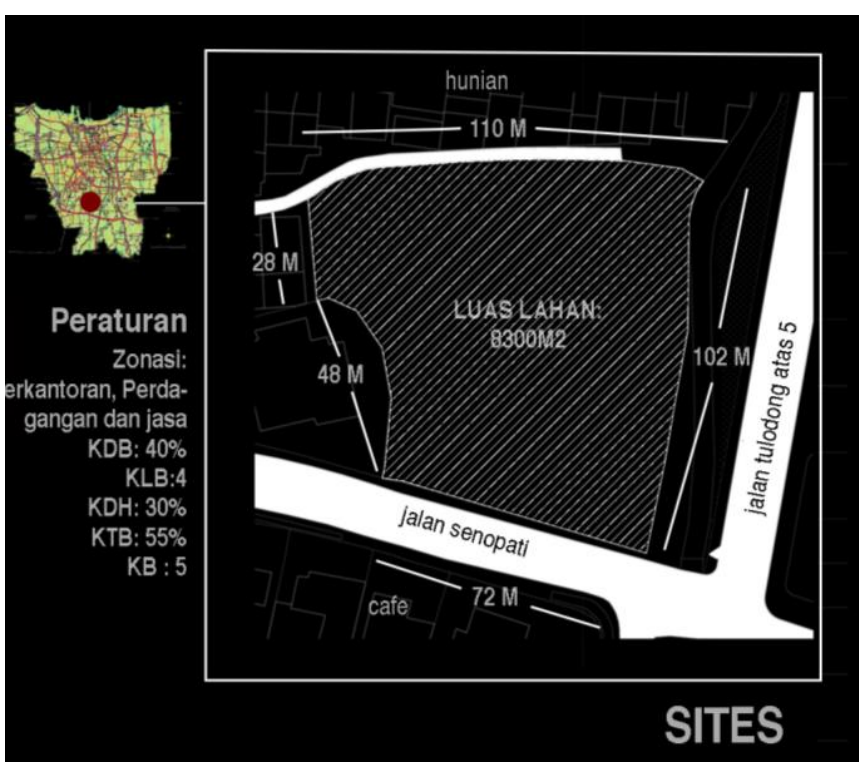

Gambar 6. Tapak Bangunan Sumber: Penulis, 2019

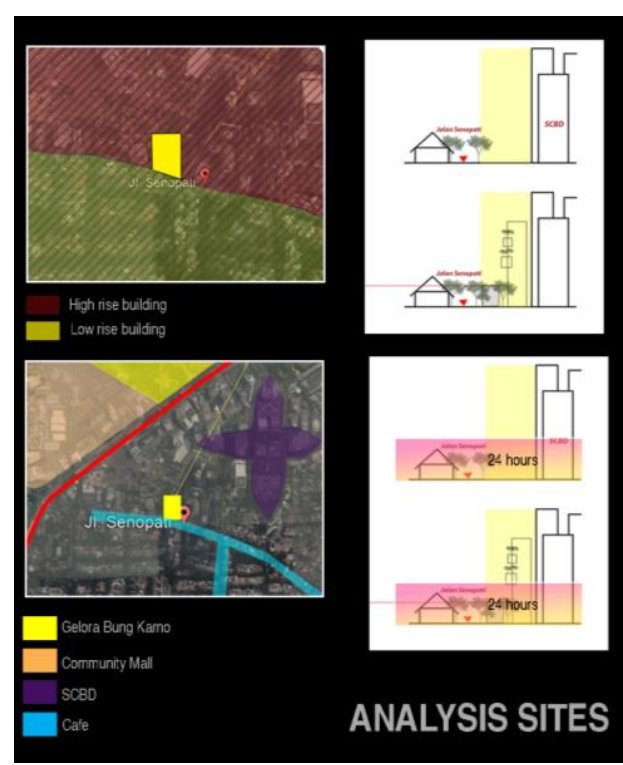

Gambar 7. Analisis Tapak Sumber: Penulis, 2019 


\section{DISKUSI DAN HASIL}

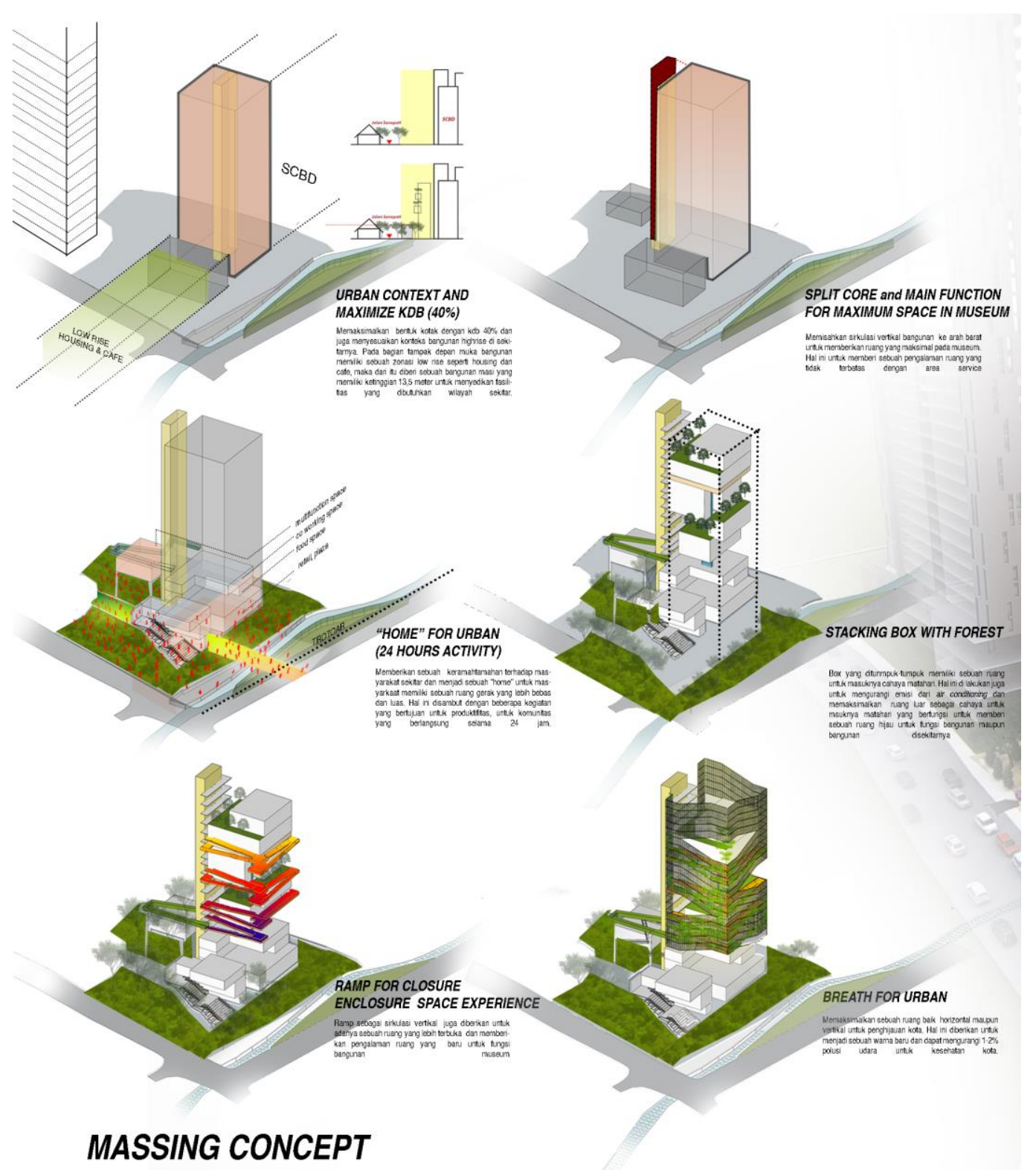

Gambar 8. Massing Concept

Sumber: Penulis, 2019

Berdasarkan kebutuhan akan sebuah ruang yang lebih maksimal, perancang membuat sebuah massa dari adaptasi sebuah lingkungan dan juga kebutuhan akan fungsi utama bangunan, dimana di dalamnya memiliki sebuah alasan :

a. Konteks bangunan dan maksimalisasi peraturan pemerintah

Bentuk bangunan highrise pada lingkungan sekitar memiliki tipologi bentuk yaitu kotak, dan pada bagian belakang bangunan merupakan sebuah lingkungan yang dipenuhi oleh gedung tinggi dan pada muka bangunan memiliki sebuah lingkungan hunian yang lowrise. Hal ini mempengaruhi bentuk awal bangunan dimana menyesuaikan dengan ketinggian pada muka bangunan.

b. Memisahkan core dengan bangunan utama

Museum sangat erat dengan sirkulasi yang menerus dan ruangan yang lapang untuk terjadinya sebuah pergerakan manusia dan penempatan objek yang lebih maksimal, oleh sebab itu core/ tempat service dipisahkan pada fungsi utama. 


\section{c. "Home" for urban}

Kegiatan yang produktif membuat ruang kota memiliki waktu yang tidak terbatas. Hal ini membuat ruang-ruang pada lingkungan produktif harus menyediakan sebuah kegiatan yang positif untuk kehidupan perkotaan di dalamnya. Pada Museum ini terdapat fasilitas yang mendukung adanya kreativitas dan produktifitas agar menghasilkan komunitas yang lebih produktif lagi seperti : co-working space, mini library, food space, mini forest, plaza, multifunction hall. Ruang yang berfungsi selama 24 jam ini juga memiliki beberapa unsur yang meneduhkan seperti mini forest dan wadah untuk terjadinya kegiatan seperti art performance.

d. Stacking box with forest

Gubahan massa pada museum disusun seperti box yang ditumpuk karena ingin memanfaatkan sebuah ruang dalam yang maksimal tetapi tetap memiliki ruang gerak yang lebih bebas. Gubahan yang disusun berdasarkan kapasitas setiap kebutuhan ruangnya. Lalu dimaksimalkan dengan taman sehingga tetap memiliki ruang hijau meskipun di atas bangunan vertikal.

e. Ramp sebagai Traffic Space dan juga pengalaman ruang eksterior dan interior sebuah bangunan

Ramp diletakkan pada luar box karena selain memanfaatkan bagian luar bangunan, sirkulasi yang menjadi benang merah terhadap desain ini juga di dalam ramp ini terdapat pot yang dapat menjadi wadah untuk penghijauan di dalamnya. Ramp disini memberi pengalaman ruang yang baru dari museum yang tertutup dan memberikan kesan yang terbuka dan lebih luas (Gambar 18).

f. Breath for Urban

Pada penelitian yang dilakukan oleh ilmuwan dari Universitas Birmingham dan Lancaster berargumentasi bahwa "greening up" jalanan dapat mengurangi 30\% reduksi pada polusi udara. Maka pada sisi luar muka bangunan diberi sebuah skin yang menjadi wadah untuk tanaman merambat sehingga penghijauan terjadi di setiap elemen bangunan, vertikal dan horizontal, 2 dimensi maupun 3 dimensi yang dapat memberi pengalaman baru dan dapat memberikan kontribusi udara yang lebih sehat terhadap lingkungan.

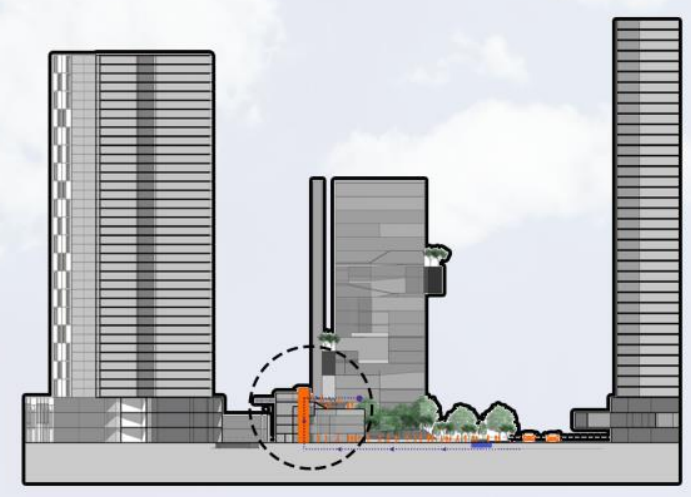

Gambar 9. Sky line bangunan dan penerapan sirkulasi utama pada bangunan Sumber: Penulis, 2019

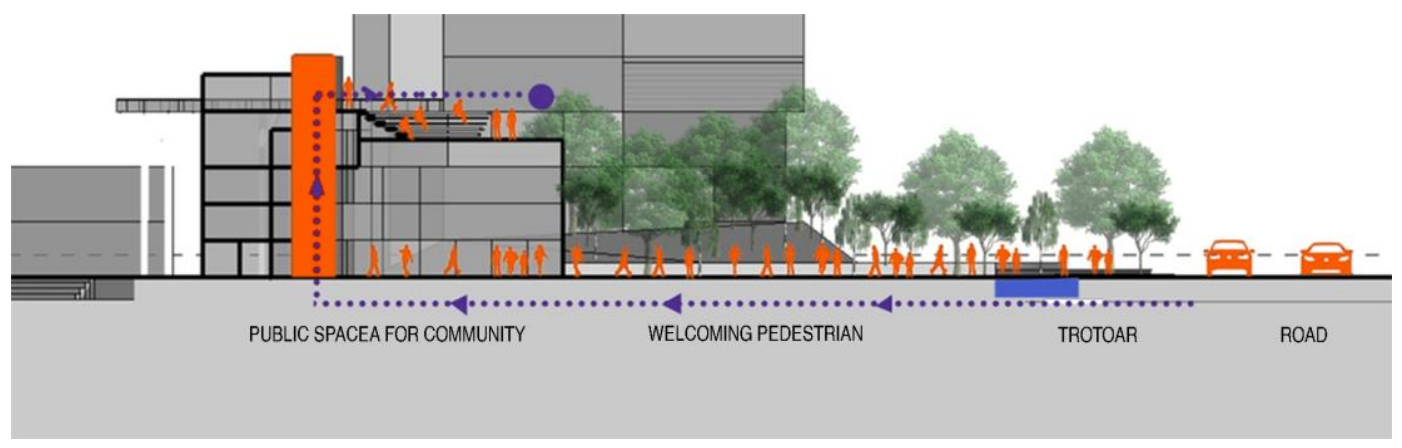

Gambar 10. Sirkulasi utama pada bangunan Sumber: Penulis, 2019 
Desain museum yang sangat mengutamakan pedestrian (Gambar 11) dalam bangunan memberikan sebuah sirkulasi yang bebas pada lantai dasar hingga lantai 4 bangunan, dilengkapi dengan beberapa fasilitas yang mendukung kebutuhan pedestrian setempat maupun di luar kawasan. Kehadiran bangunan massa di bagian muka bangunan memberi ruang gerak yang bebas dan menyambut para pedestrian ke dalam bangunan. Tetapi di dalamnya juga terdapat sirkulasi vertikal yang mengarahkan pengunjung langsung menuju lobby museum (Gambar 12).

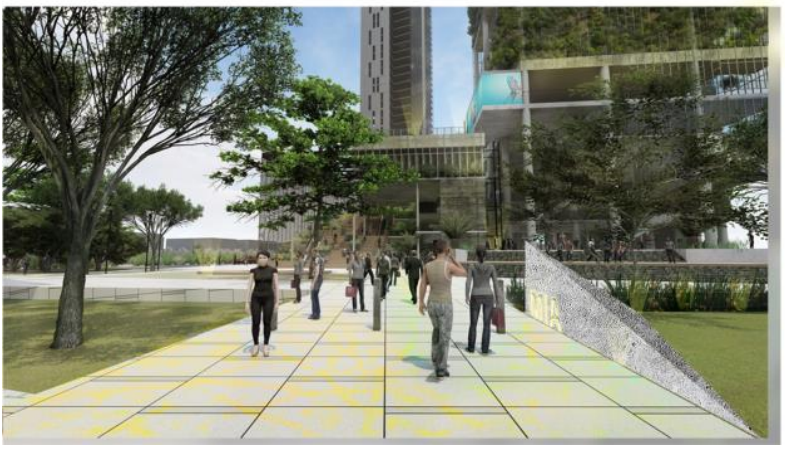

Gambar 11. Main Entrance

Sumber: Penulis, 2019

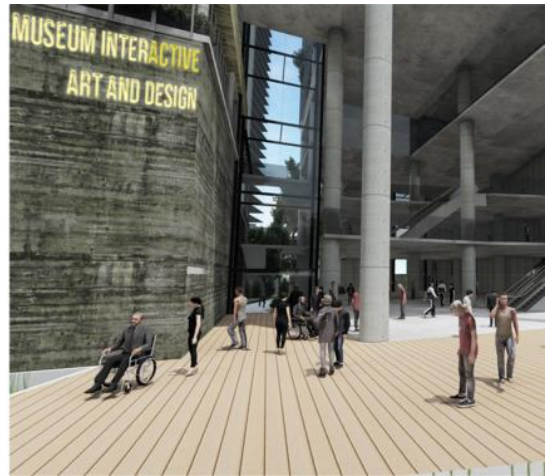

Gambar 12. Lift menuju lobby Sumber: Penulis, 2019

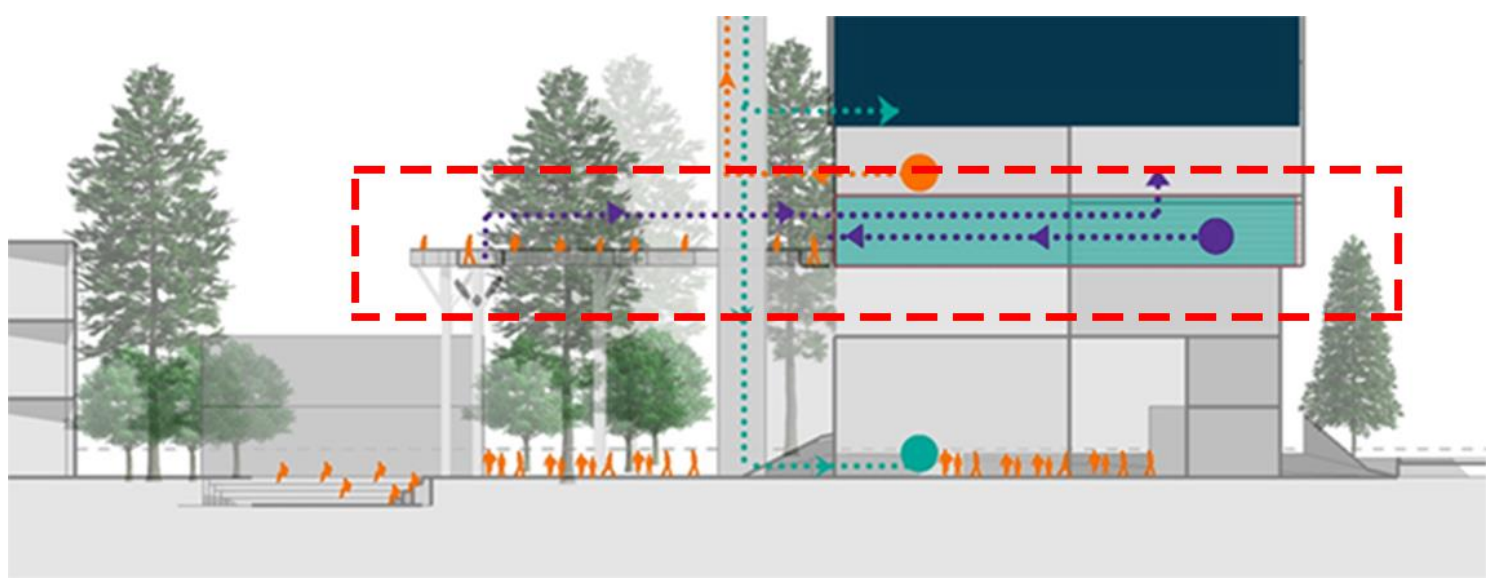

Gambar 13. Sirkulasi Awal Pada Museum

Sumber: Penulis, 2019

Pada sirkulasi awal museum di dalamnya terdapat lobby (Gambar 14) untuk administrasi lalu pengunjung dibawa ke luar bangunan sebagai sirkulasi utama pada museum ini. Desain jembatan (Gambar 15) pada museum merupakan representasi dari alam merupakan sebuah dasar dari seni dan desain. Desain jembatan setinggi 20 meter dari permukaan jalan dibuat terbuka dan dikelilingi oleh hutan kecil dan menggunakan elemen lantai dan railing yang terbuka yaitu menggunakan perforated wall.

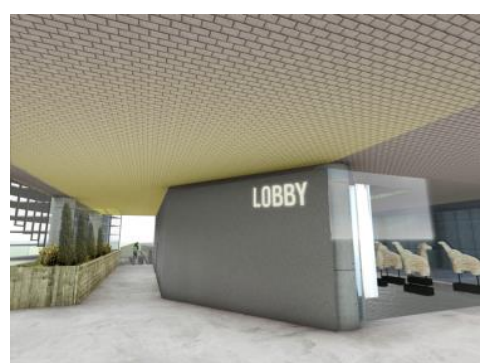

Gambar 14. Lobby Museum Sumber: Penulis, 2019

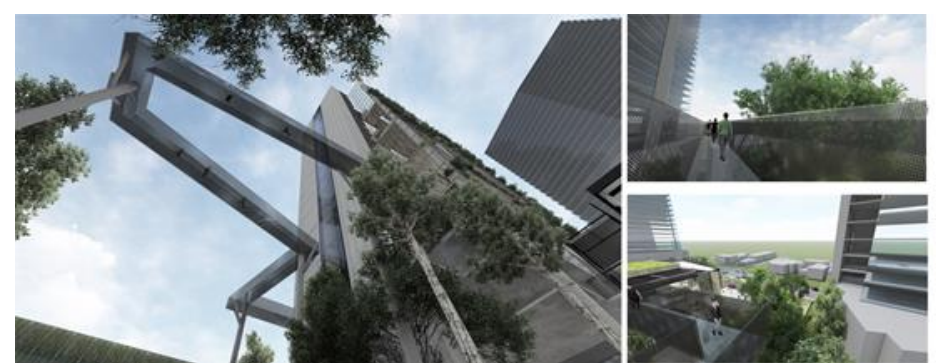

Gambar 15. Jembatan Museum

Sumber: Penulis, 2019 


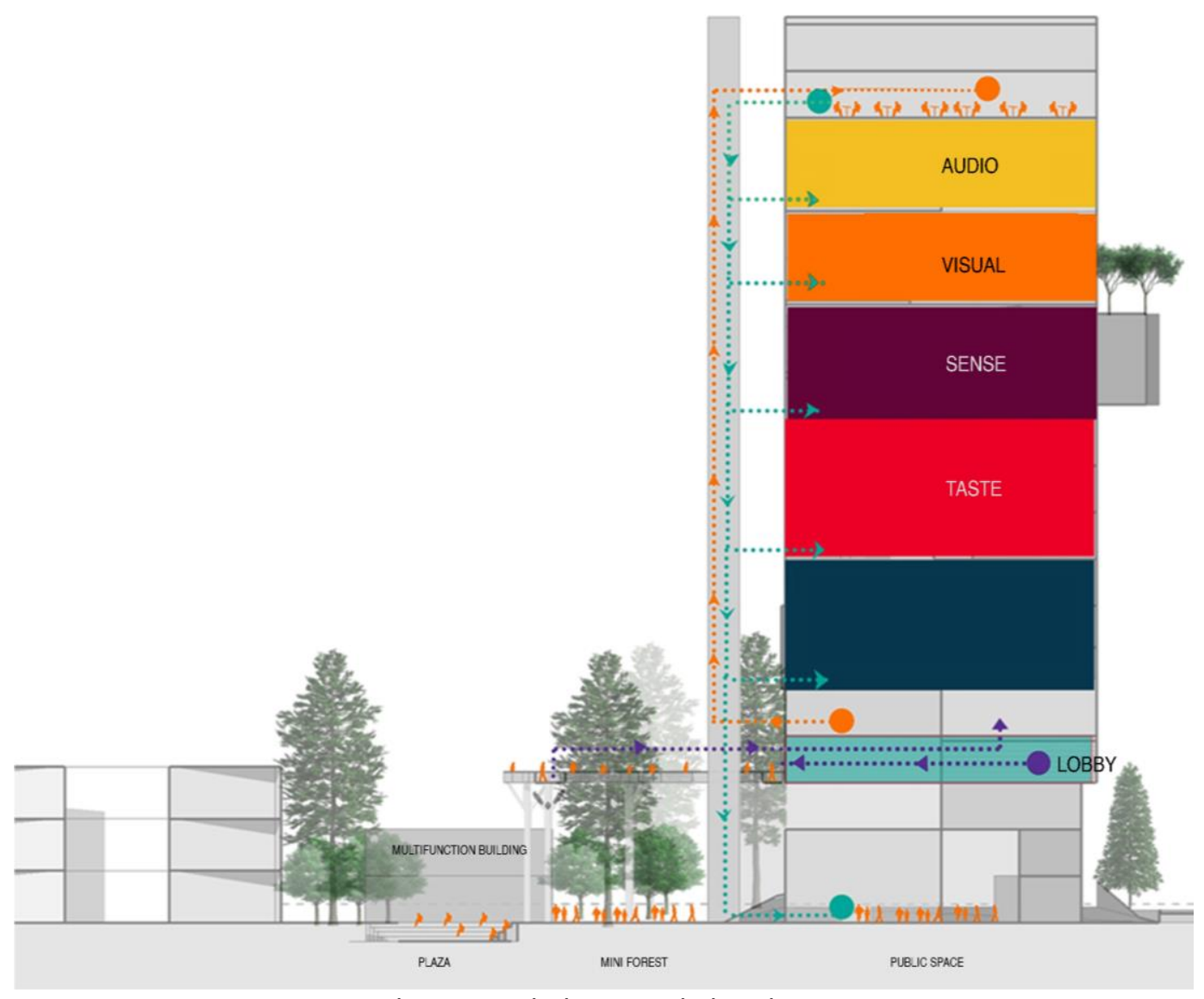

Gambar 16. Sirkulasi Vertikal Pada Museum Sumber: Penulis, 2019
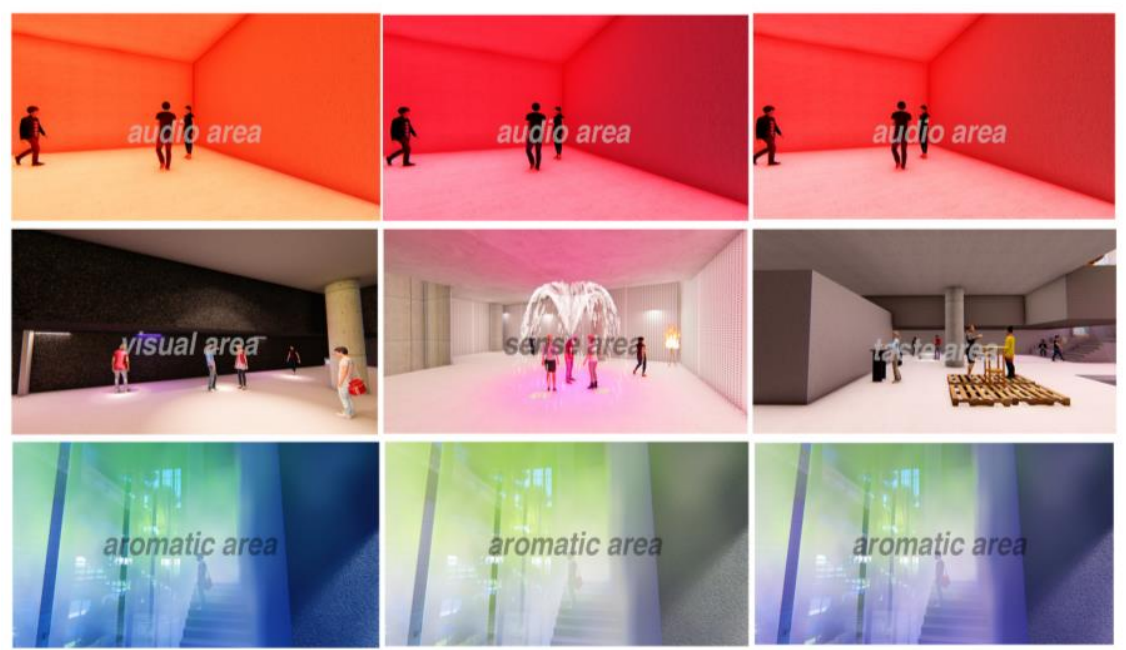

Gambar 17. Ruang "Five Senses of Human"

Sumber: Penulis, 2019

Sirkulasi museum (Gambar 16) memberikan sebuah strategi dalam desain untuk mengatur pergerakan manusia supaya lebih efisien. Memberikan ruang yang berbeda sehingga semua konten pada museum dapat dirasakan oleh para pengunjung. Perancang memberi ruang untuk pengunjung setelah melewati jembatan museum lalu pengunjung dibawa ke lantai 19 untuk melihat infografik dari semua konten pada museum. Lalu pengunjung bebas bergerak ke lantailantai bawahnya untuk menikmati setiap konten "Five Senses of Human" yang ada (Gambar 17). 

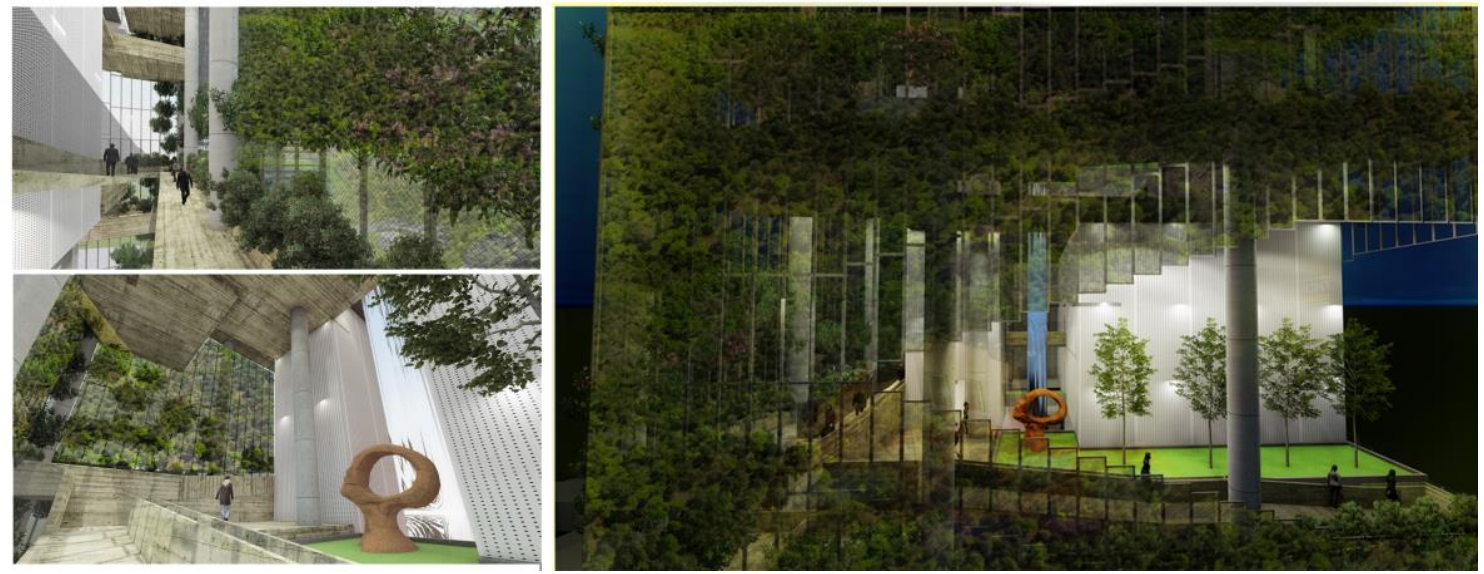

Gambar 18. Ramp Di Luar Ruangan

Sumber: Penulis, 2019

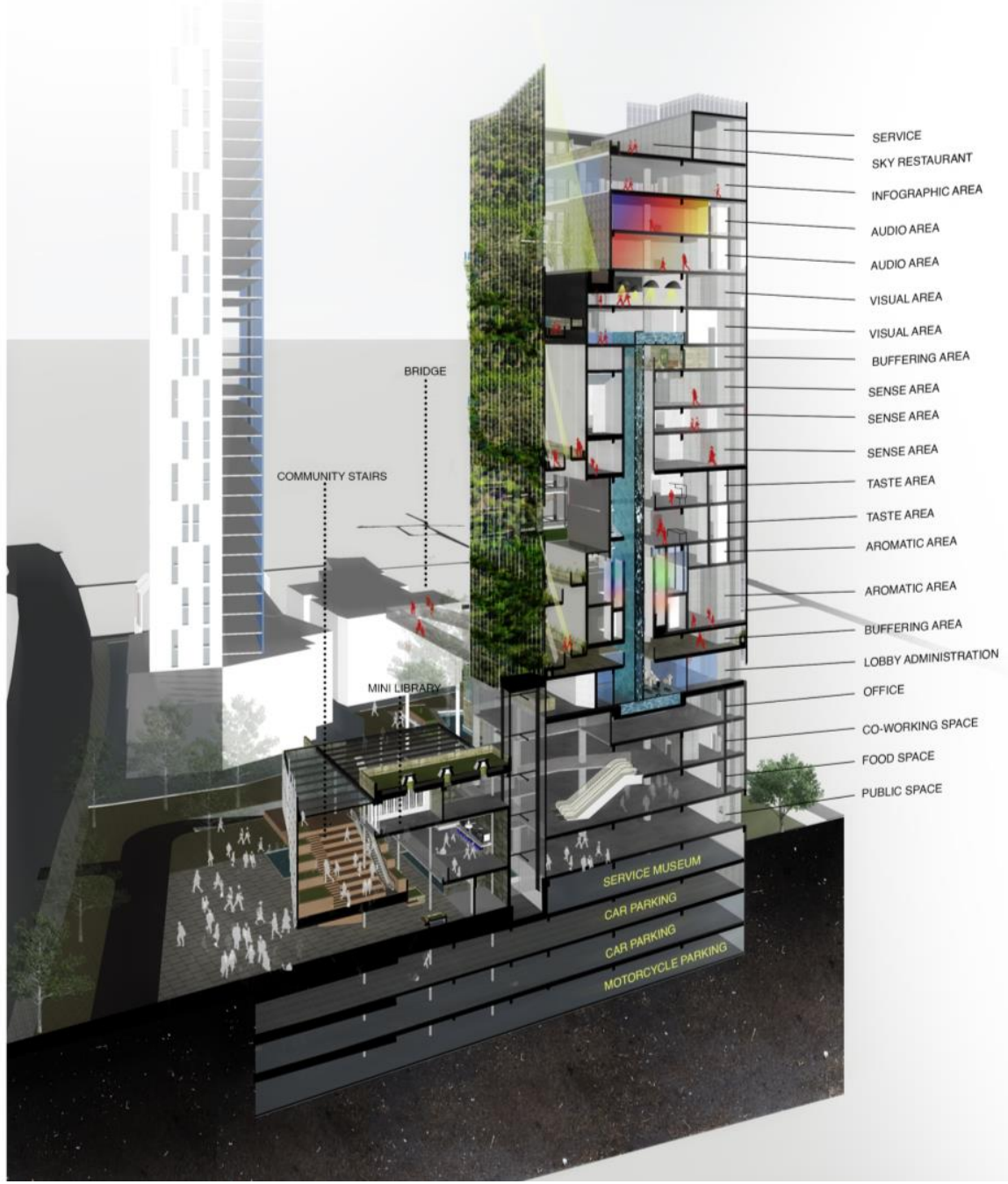

Gambar 19. Potongan Perspektif

Sumber: Penulis, 2019 


\section{PROGRAMATIK}

\begin{tabular}{|ll|}
\hline $\begin{array}{l}\text { MUSEUM } \\
\text { Lobby }\end{array}$ & $300 \mathrm{~m} 2$ \\
Bridge & $150 \mathrm{~m} 2$ \\
Buffering area & $1790 \mathrm{~m} 2$ \\
Aromatic area & $700 \mathrm{~m} 2$ \\
Taste area & $630 \mathrm{~m} 2$ \\
garden outdoor & $313 \mathrm{~m} 2$ \\
sense area & $126 \mathrm{~m} 2$ \\
visual area & $950 \mathrm{~m} 2$ \\
audio area & $750 \mathrm{~m} 2$ \\
infographic area & $460 \mathrm{~m} 2$ \\
& \\
EDUCATION & \\
Mini Library & $300 \mathrm{~m} 2$ \\
HOSPITALITY & \\
Public Space & $814 \mathrm{~m} 2$ \\
Mushola & $36 \mathrm{~m} 2$ \\
Community Stair & $351 \mathrm{~m} 2$ \\
Co Working Space & $300 \mathrm{~m} 2$ \\
& \\
OFFICE & \\
Marketing Office & $174 \mathrm{~m} 2$ \\
Museum Office & $300 \mathrm{~m} 2$ \\
Museum Marketing & \\
office & $140 \mathrm{~m} 2$ \\
& \\
COMMERCIAL & \\
Multifunction building & $550 \mathrm{~m} 2$ \\
Food space & $888 \mathrm{~m} 2$ \\
Tenant \\
Commercial & $100 \mathrm{~m} 2$ \\
Sky Restaurant & $290 \mathrm{~m} 2$ \\
& $460 \mathrm{~m} 2$ \\
& \\
& \\
\hline
\end{tabular}

\section{$|+|||$}
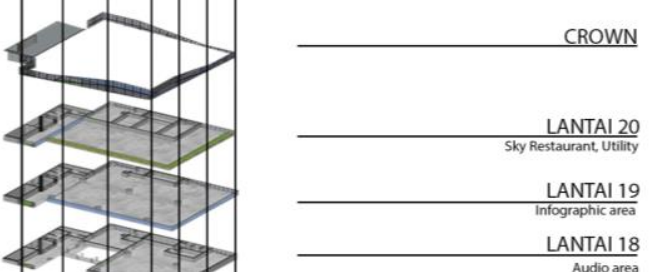

Audio area

LANTAI 17

$\frac{\text { LANTAL } 16}{\text { Visual area }}$

LANTAI 15

LANTAI 14

LANTAI 13

LANTAI 12

LANTAI 11

LANTAI 10

LANTAI 9

LANTAI 8
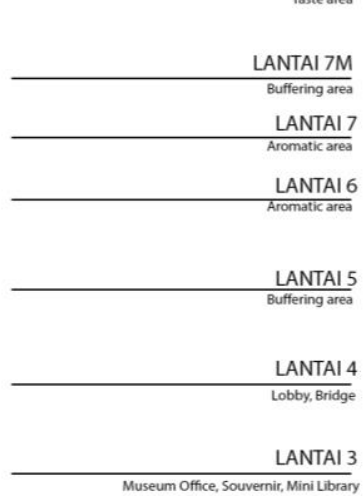

\section{LANTAI 2}

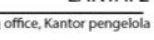

LANTAI
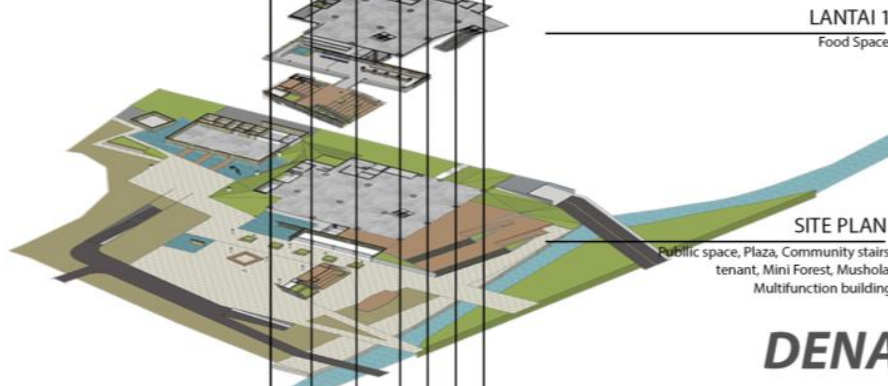

DENAH EXPLODED

Gambar 20. Denah Exploded

Sumber: Penulis, 2019 


\section{KESIMPULAN DAN SARAN}

Museum Interaktif Seni dan Desain yang terletak di kegiatan perkotaan yang sangat padat bisa menjadi solusi untuk menunjang konteks hiruk pikuk kota. Seni menjadi katalisator dalam menjadikan kota yang lebih kreatif. Konten "Five Senses of Human" yang bertujuan untuk menjadikan manusia lebih peka akan lingkungan sekitarnya. Wadah tersebut untuk menunjang interaksi sebagai wujud dari eksistensi manusia, objek dan alam. Museum adalah bangunan kultur yang sangat erat dengan interaksi manusia. Maka dari itu desain mengacu kepada pendekatanpendakatan fungsi yang menunjang adanya interaksi manusia. Fungsi seperti co-working space, mini library, multifunction building, plaza, food space dapat menjadi penunjang yang akan menunjang fungsi utama dan kebutuhan produktifitas kota.

Dalam mewujudkan desain museum yang terletak di tengah perkotaan dibutuhkan adanya pendekatan akan konsep alam untuk menghadirkan kota yang berkelanjutan. Pendekatan massa bangunan highrise beradaptasi dari sebuah bangunan tinggi yang monoton. Hal ini akan memberikan kesegaran untuk masyarakat agar bisa membawa lingkungannya untuk lebih berkelanjutan. Desain ruang publik yang menunjang fungsi utama museum akan menjadi lingkungan yang memberikan kesan "home" untuk masyarakatnya.

\section{DAFTAR PUSTAKA}

Handerson, J. (2001). In : Sun Huo (Ed) Trans. Museum Architecture. Beijing : China Light Industry Press.

Zhang, J. Z. C. (1998). Exhibition Architecture. Nanchang : Jiangxi Science and Technology Press.

Spirn, AW, "Air quality at the Street Level: Strategies for Urban Design", Cambridge, Harvard Graduate School of Design (1986) diunduh 15 Juni 2019, http://web.mit.edu/nature/archive/student_projects/2009/jcalamia/Frame/06_canyonpoll ution.html

http://urbanplanning.uonbi.ac.ke/sites/default/files/cae/artsdesign/urbanplanning/T2-2\%20\%20URBAN\%20ANALYSIS.pp diunduh 18 Juni 2019 
